\title{
Hydrogen Sulfide Maintained the Good Appearance and Nutrition in Post-harvest Tomato Fruits by Antagonizing the Effect of Ethylene
}

OPEN ACCESS

Edited by:

Cai-Zhong Jiang,

Crops Pathology and Genetics Research Unit, USDA-ARS,

United States

Reviewed by:

María Serrano,

Universidad Miguel Hernández

de Elche, Spain

Daniel Alexandre Neuwald,

Competence Centre for Fruit

Growing - Lake Constance, Germany

${ }^{*}$ Correspondence:

Kang-Di Hu

kangdihu@hfut.edu.cn

Hua Zhang

hzhanglab@hfut.edu.cn

${ }^{\dagger}$ These authors have contributed equally to this work

Specialty section:

This article was submitted to Crop and Product Physiology,

a section of the journal Frontiers in Plant Science

Received: 14 February 2020 Accepted: 17 April 2020

Published: 14 May 2020

Citation:

Yao G-F, Li C, Sun K-K, Tang J,

Huang $Z-Q$, Yang $F$, Huang $G-G$, $H u L-Y$, Jin $P, H u K-D$ and Zhang $H$ (2020) Hydrogen Sulfide Maintained the Good Appearance and Nutrition

in Post-harvest Tomato Fruits by

Antagonizing the Effect of Ethylene.

Front. Plant Sci. 11:584.

doi: 10.3389/fpls.2020.00584

\section{Gai-Fang Yao ${ }^{1 \dagger}$, Chuang $\mathrm{Li}^{1+}$, Ke-Ke Sun ${ }^{1 \dagger}$, Jun Tang ${ }^{2}$, Zhong-Qin Huang ${ }^{2}$, Feng Yang ${ }^{2}$, Guan-Gen Huang ${ }^{1}$, Lan-Ying Hu', Peng Jin ${ }^{3}$, Kang-Di Hu' ${ }^{1 *}$ and Hua Zhang ${ }^{1 *}$}

${ }^{1}$ School of Food and Biological Engineering, Hefei University of Technology, Hefei, China, ${ }^{2}$ Xuzhou Institute of Agricultural Sciences of the Xuhuai District of Jiangsu Province, Xuzhou, China, ${ }^{3}$ Department of Ecology and Environment of Anhui Province, Hefei, China

Hydrogen sulfide $\left(\mathrm{H}_{2} \mathrm{~S}\right)$ could act as a versatile signaling molecule in delaying fruit ripening and senescence. Ethylene $\left(\mathrm{C}_{2} \mathrm{H}_{4}\right)$ also plays a key role in climacteric fruit ripening, but little attention has been given to its interaction with $\mathrm{H}_{2} \mathrm{~S}$ in modulating fruit ripening and senescence. To study the role of $\mathrm{H}_{2} \mathrm{~S}$ treatment on the fruit quality and nutrient metabolism, tomato fruits at white mature stage were treated with ethylene and ethylene plus $\mathrm{H}_{2} \mathrm{~S}$. By comparing to $\mathrm{C}_{2} \mathrm{H}_{4}$ treatment, we found that additional $\mathrm{H}_{2} \mathrm{~S}$ significantly delayed the color change of tomato fruit, and maintained higher chlorophyll and lower flavonoids during storage. Moreover, $\mathrm{H}_{2} \mathrm{~S}$ could inhibit the activity of protease, maintained higher levels of nutritional-related metabolites, such as anthocyanin, starch, soluble protein, ascorbic acid by comparing to $\mathrm{C}_{2} \mathrm{H}_{4}$ treatment. Gene expression analysis showed that additional $\mathrm{H}_{2} \mathrm{~S}$ attenuated the expression of beta-amylase encoding gene BAM3, UDP-glycosyltransferase encoding genes, ethylene-responsive transcription factor ERFOO3 and DOF22. Furthermore, principal component analysis suggested that starch, titratable acids, and ascorbic acid were important factors for affecting the tomato storage quality, and the correlation analysis further showed that $\mathrm{H}_{2} \mathrm{~S}$ affected pigments metabolism and the transformation of macromolecular to small molecular metabolites. These results showed that additional $\mathrm{H}_{2} \mathrm{~S}$ could maintain the better appearance and nutritional quality than $\mathrm{C}_{2} \mathrm{H}_{4}$ treatment alone, and prolong the storage period of post-harvest tomato fruits.

Keywords: hydrogen sulfide, ethylene, tomato fruits, nutritional quality, post-harvest ripening

\section{INTRODUCTION}

Ripening of fleshy fruit is composed of a series of complex and coordinated processes that leading to edible fruit with desirable flavor (Karlova et al., 2014). However, fruit excessive ripening will cause senescence and deterioration during storage, which finally leads to shortened shelf life and reduction in commercial value (Lee et al., 2010). In this process, fruit ripening is accompanied

Abbreviations: $\mathrm{C}_{2} \mathrm{H}_{4}$, ethylene; $\mathrm{CHL}$, chlorophyllase; $\mathrm{CO}$, carbon monoxide; DAS, day after storage; EDTA, ethylene diamine tetraacetic acid; FW, fresh weight; G-O, green-orange; G-Y, green-yellow; $\mathrm{H}_{2} \mathrm{~S}$, hydrogen sulfide; L-R, light red; NO, nitric oxide; O-R, orange-red; PCA, principal component analysis; PPH, pheophytinase; TA, titratable acid; UFGT, UDP glucose: flavonoid-3-O-glucosyltransferase. 
by profound physiological and transcriptome changes, such as cell wall component degradation, accumulation of sugar and reduction of organic acids, increased volatile compounds, degradation of chlorophyll and accumulation of pigments (Klee and Giovannoni, 2011; Gapper et al., 2013). Ethylene is a gaseous phytohormone that regulates the whole life cycle of plants, including plant growth and development, fruit ripening and organ senescence, plant biotic and abiotic stress, and extensively investigated in a large number of crops (Dubois et al., 2018). Fleshy fruits could be classified as climacteric and non-climacteric which is defined by whether an increase in respiration and concomitant increase in ethylene biosynthesis happened after the start of ripening (Klee and Giovannoni, 2011). In climacteric fruit like tomato, ripening is initiated by ethylene and exogenous ethylene could also promote fruit ripening (Liu et al., 2015). Ethylene coordinates the ripening process and acts in concert with other phytohormones. Chen et al. (2019) reported that exposure to ethylene improved sucrose accumulation in ripening sugarcane. In addition, carotenoid accumulation is modulated by the auxin-ethylene balance during tomato fruit ripening; strawberry fruit ripening was regulated by ABA, IAA, and ethylene (Su et al., 2015; Guo et al., 2018).

Hydrogen sulfide $\left(\mathrm{H}_{2} \mathrm{~S}\right)$ is a small gasotransmitter that plays an important role in diverse plant physiological processes such as plant adaptation to stress conditions, stomatal movement, root development, autophagy and flower senescence (Hancock and Whiteman, 2016). Accumulating evidence reported that $\mathrm{H}_{2} \mathrm{~S}$ delayed senescence in post-harvest fruits and vegetables, including apple, kiwifruit, broccoli, and strawberry, etc. (Zhang et al., 2011; Hu et al., 2012; Li et al., 2014; Zhu et al., 2014; Zheng et al., 2016). Previous researches reported that $\mathrm{H}_{2} \mathrm{~S}$ maintains higher metabolites levels in broccoli and strawberry, such as carotenoids, anthocyanin, ascorbic acid, reducing sugars and soluble proteins (Hu et al., 2012; Li et al., 2014). During kiwifruit storage, $\mathrm{H}_{2} \mathrm{~S}$ played an important role in delaying kiwifruit ripening and senescence and maintaining higher level of titratable acid and ascorbic acid by repression of ethylene production (Zhu et al., 2014). Meanwhile, $\mathrm{H}_{2} \mathrm{~S}$ could protect lipid from peroxidation by improving antioxidative enzyme activities and decreasing the accumulation of reactive oxygen species (ROS) (Zhu et al., 2014). All the evidence showed that ethylene and $\mathrm{H}_{2} \mathrm{~S}$ regulate climacteric fruit ripening and senescence, whereas the interaction of $\mathrm{H}_{2} \mathrm{~S}$ with ethylene in controlling the post-harvest fruit ripening and the nutritional quality are rarely reported.

Tomato (Solanum lycopersicum) is one of the most studied fleshy fruit, and it has been assumed as a "functional food" because of the evidence regarding to the reduced risk of cancer and cardiovascular diseases in relationship to its consumption (Giovannetti et al., 2012). Their benefits to human health are primarily associated with the bioactive compounds in fruit such as lycopene, ascorbic acid, tocopherols and polyphenols, carotenoids, anthocyanins (Giovannetti et al., 2012; Vinha et al., 2014). However, tomato is not resistant to storage and prone to rot, thus resulting in economic loss.

In our recent studies, $\mathrm{H}_{2} \mathrm{~S}$ was found to alleviate tomato fruit ripening by reducing ROS accumulation, and meanwhile ethylene biosynthesis and signaling pathway were inhibited by $\mathrm{H}_{2} \mathrm{~S}$ (Yao et al., 2018; $\mathrm{Hu}$ et al., 2019). Though $\mathrm{H}_{2} \mathrm{~S}$ has been found to be a senescence regulator in diverse fruits and vegetables, the mechanism of exogenous $\mathrm{H}_{2} \mathrm{~S}$ in affecting the bioactive compounds of ethylene-induced tomato fruit ripening and senescence is still obscure. In the present research, we tried to explore the effect of $\mathrm{H}_{2} \mathrm{~S}$ on the mentalism of the bioactive compounds in $\mathrm{C}_{2} \mathrm{H}_{4}$-induced tomato fruit ripening by comparing to $\mathrm{C}_{2} \mathrm{H}_{4}$ treatment alone. Tomato fruits of the cultivar "Micro Tom" at white mature stage were fumigated with exogenous $\mathrm{C}_{2} \mathrm{H}_{4}$ or $\mathrm{C}_{2} \mathrm{H}_{4}$ plus $\mathrm{H}_{2} \mathrm{~S}$, and the bioactive compounds and the expressions of genes involving in nutrient metabolism were investigated during post-harvest storage. Furthermore, PCA, the correlation and the change patterns among the bioactive compounds were analyzed to explore the underlying physiological mechanism.

\section{MATERIALS AND METHODS}

\section{Plant Materials and Treatment}

Tomato fruits of the cultivar "Micro Tom" were harvested in the man-made glasshouse of School of Food and Biological Engineering, Hefei University of Technology, Anhui province, China. Fruit without pest or mechanical damage were harvested at white mature stage. Random eight fruits were used as one group, and each experiment was composed of three groups. NaHS (purchased from Sigma) was used as the donor of $\mathrm{H}_{2} \mathrm{~S}$ and ethephon in aqueous solution for $\mathrm{C}_{2} \mathrm{H}_{4}$ donor. $\mathrm{C}_{2} \mathrm{H}_{4}$ treatment was proceeded with a $100 \mathrm{~mL}$ of $1.0 \mathrm{~g} / \mathrm{L}$ ethephon aqueous solution. $\mathrm{C}_{2} \mathrm{H}_{4}+\mathrm{H}_{2} \mathrm{~S}$ co-treatment was composed of a $150 \mathrm{~mL}$ of $0.90 \mathrm{mmol} \cdot \mathrm{L}^{-1} \mathrm{NaHS}$ aqueous solution and a $100 \mathrm{~mL}$ of $1.0 \mathrm{~g} / \mathrm{L}$ ethephon aqueous solution. The above samples were placed in $3 \mathrm{~L}$ sealed containers. Tomato fruits were fumigated by $\mathrm{C}_{2} \mathrm{H}_{4}$ or $\mathrm{C}_{2} \mathrm{H}_{4}+\mathrm{H}_{2} \mathrm{~S}$ for $24 \mathrm{~h}$ and the fruits were fumigated by equal amount of distil water. The tomato flesh (without seeds) were sampled every day till 7 days after storage and frozen in liquid $\mathrm{N}_{2}$ quickly and stored in $-80^{\circ} \mathrm{C}$ refrigerator.

\section{Determination of Color Change of Tomato Fruits}

Color change of tomato fruits was measured by a colorimeter (model WSC-100, Japan) as shown in $\mathrm{Hu}$ et al. (2012) with some modification. Each tomato fruit at the equatorial part was selected for the determination, and the value of $a^{*} / b^{*}$ showed color change of fruit surface.

\section{Determination of Chlorophyll and Carotenoid Contents}

Chlorophyll and carotenoid contents of tomato fruits were assayed according to the method of Wellburn (1994). $2.0 \pm 0.01 \mathrm{~g}$ of fresh tomato sample was ground and extracted by ethanol and $80 \%$ acetone solution in a ratio of $1: 1(\mathrm{v} / \mathrm{v})$. The absorbance was measured at 663, 645, and $440 \mathrm{~nm}$. Three replicates were performed for each sample and the results were expressed as $\mathrm{mg} / \mathrm{g}$ FW (fresh weight). 


\section{Determination of Flavonoids, Total Phenols, and Anthocyanin Contents}

The flavonoids contents were determined by aluminum chloride colorimetric assay by measuring the absorbance at $510 \mathrm{~nm}$ ( $\mathrm{Li}$ et al., 2014). Rutin was used as the standard for calibration.

Total phenols were assayed following the method of Pirie and Mullins (1976). The total phenols in fruit was determined by spectrophotometer at $280 \mathrm{~nm}$. Gallic acid was used as the standard to make a calibration curve.

Anthocyanin content was extracted and determined according to the protocol described by Lee and Wicker (1991). $2.0 \pm 0.01 \mathrm{~g}$ of tomato fruits were ground with $10 \mathrm{~mL}$ of $0.1 \% \mathrm{HCl}$-methanol solution. The absorbance was recorded at 530,620 , and $650 \mathrm{~nm}$ and anthocyanin content were expressed as $\mathrm{mg} / \mathrm{g} \mathrm{FW}$.

\section{Determination of Ascorbic Acid, Titratable Acids, and Reducing Sugar Content}

Ascorbic acid was assessed by the indophenol titration method with minor changes (Nath et al., 2011). $5.00 \pm 0.01 \mathrm{~g}$ of fruit sample was homogenized with $5 \mathrm{~mL}$ of $2 \%$ oxalic acid followed by centrifugation at $12000 \mathrm{~g}$ for $30 \mathrm{~min}$. The supernatant was adjusted to $25 \mathrm{~mL}$ with $2 \%$ oxalic acid and titrated with 2,6dichlorophenol-indophenol to a pink color and maintain a pink color in $30 \mathrm{~s}$.

The titratable acid content was determined by the method adapted from Bureau et al. (2009). $5.00 \pm 0.01 \mathrm{~g}$ of tomato homogenates were mixed with $20 \mathrm{~mL}$ distilled water. Then, mixture was used for acid-base neutralization to measure the titratable acid content. The volume of $\mathrm{NaOH}$ was recorded to calculate the content of titratable acids.

The content of reducing sugar was assessed according to the method of Miller (1959) with some modifications. $2.00 \pm 0.01 \mathrm{~g}$ of tomato samples were ground with $5 \mathrm{~mL}$ of $0.1 \mathrm{M} \mathrm{Na}$-acetate buffer with the enzyme solution (both solutions were preheated at $50^{\circ} \mathrm{C}$ for $5 \mathrm{~min}$ ). The absorbance at $540 \mathrm{~nm}$ was recorded to measure the content of reducing sugar with glucose as the standard to make a calibration curve. Three replicates were performed for each sample and the results were expressed as $\mathrm{mg} / \mathrm{g}$ FW (fresh weight).

\section{Determination of the Contents of Soluble Protein and Starch}

The content of soluble protein was assayed following the method of Bradford (1976). Absorption of soluble protein was recorded at $595 \mathrm{~nm}$. The content of starch in tomato fruits was determined referring to the method by Zhang et al. (2012). $2.0 \mathrm{~g}$ of tomato fruits was homogenized with $3 \mathrm{~mL}$ of $80 \%$ ethanol solution. The content of starch was determined at $510 \mathrm{~nm}$, and soluble starch was used as the standard for calibration.

\section{Determination of Proteolytic Enzyme and Amylase Activity}

For the activity of protease, tomato flesh $(2.0 \pm 0.01 \mathrm{~g})$ were ground in $5 \mathrm{~mL}$ of ice-cold Tris- $\mathrm{HCl}$ buffer [50 mM, pH 7.5, included $1 \mathrm{mM}$ EDTA, $15 \mathrm{mM} \beta$-mercaptoethanol, and $1 \%$ polyvinyl pyrrolidone (PVP)]. The homogenate was centrifuged and then the supernatant was collected for protease activity determination (Reimerdes and Klostermeyer, 1976). Absorbance was recorded at $540 \mathrm{~nm}$, and the activity of protease was quantified as U/g FW.

The activity of amylase was determined according to the method of Staden and Mulaudzi (2000) with some modifications. $2.00 \pm 0.01 \mathrm{~g}$ of tomato samples were homogenized with $3 \mathrm{~mL}$ of citric acid buffer ( $\mathrm{pH} 5.6,0.1 \mathrm{mM}$ ). The homogenate was centrifuged at $12000 \mathrm{~g}$ for $20 \mathrm{~min}$ at $4^{\circ} \mathrm{C}$, and the supernatant was placed in a new tube for amylase determination. One unit of enzyme activity was defined as the amount of maltose produced per gram of the sample per min, and the activity of amylase was quantified as U/g FW.

\section{Quantitative Reverse Transcription PCR Analysis}

Total RNA from $0.1 \mathrm{~g}$ frozen tomato fruit samples was extracted by RNA Extraction Kit (Tiangen, Beijing, China). Then cDNA was synthesized by reverse transcription kit (PrimeScript RT Master Mix, Takara, Kyoto, Japan) and further used for quantitative PCR. The specific primers used for qPCR were listed in Supplementary Table S1. The expression of tubulin gene in control tomato was used for the normalization of data.

\section{Statistical Analysis}

Statistical analysis was performed using $t$-test in SPSS 22.0. PCA analysis was performed using factor analysis in dimension reduction, and the rotation method was performed by Varimax with Kaiser Normalization. The correlation analysis and the heatmap analysis were performed by Rstudio software. All data are expressed as means \pm standard deviations of the values obtained by three independent measurements.

\section{RESULTS}

\section{Effect of $\mathrm{C}_{2} \mathrm{H}_{4}$ and $\mathrm{H}_{2} \mathrm{~S}-\mathrm{C}_{2} \mathrm{H}_{4}$ Treatment on Tomato Color Change During Post-harvest Storage}

The color change of tomato fruit during the post-harvest storage period was shown in Figure 1A. It is clearly showed that all the tomato fruits are at green-yellow ( $\mathrm{G}-\mathrm{Y}, \sim 30 \%$ yellow skin) period on the 0th day. A part of $\mathrm{C}_{2} \mathrm{H}_{4}$-induced tomatoes is at greenorange (G-O, $\sim 50 \%$ orange skin) period on the 1st and 2nd day, but tomato fruits are almost at $\mathrm{G}-\mathrm{Y}$ period by $\mathrm{C}_{2} \mathrm{H}_{4}+\mathrm{H}_{2} \mathrm{~S}$ cotreatment. All $\mathrm{C}_{2} \mathrm{H}_{4}$-induced tomatoes turn to orange-red (O$\mathrm{R},>90 \%$ orange or red skin) from the day 3 to day 5 . Meanwhile, some tomatoes are still at $\mathrm{G}-\mathrm{O}$ period in $\mathrm{C}_{2} \mathrm{H}_{4}-\mathrm{H}_{2} \mathrm{~S}$ co-treatment. On days 6 and 7, all $\mathrm{C}_{2} \mathrm{H}_{4}$-induced tomato fruits are at the light red (L-R, fully orange or red skin) period, but a part of tomatoes are still at $\mathrm{O}-\mathrm{R}$ period in $\mathrm{C}_{2} \mathrm{H}_{4}-\mathrm{H}_{2} \mathrm{~S}$ co-treatment.

As shown in Figure 1B, the change of color was expressed with $\mathrm{a}^{*} / \mathrm{b}^{*}$ value. During the whole storage period, the $\mathrm{a}^{*} / \mathrm{b}^{*}$ value of the two treatment groups showed an upward trend, 

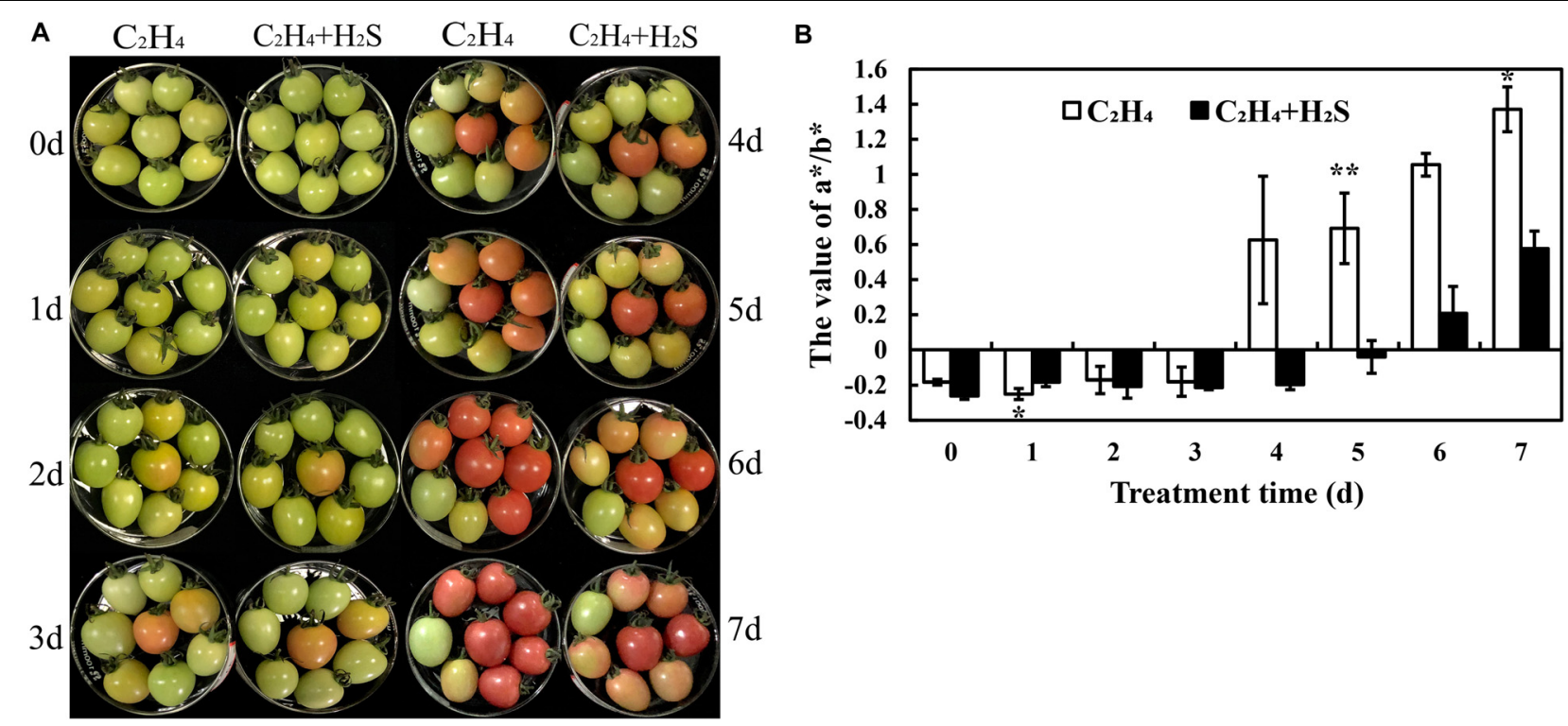

FIGURE 1 | The phenotypic change of post-harvest tomato fruits with $\mathrm{C}_{2} \mathrm{H}_{4}$ or $\mathrm{C}_{2} \mathrm{H}_{4}-\mathrm{H}_{2} \mathrm{~S}$ treatment. (A) The phenotypic change of post-harvest tomato fruits. (B) The color parameter $a^{*} / b^{*}$ value changes with $\mathrm{C}_{2} \mathrm{H}_{4}$ or $\mathrm{C}_{2} \mathrm{H}_{4}-\mathrm{H}_{2} \mathrm{~S}$ treatment during tomato post-harvest storage. $\mathrm{a}^{*}$ value represents a range from magenta to green, and $b^{\star}$ value represents a range from yellow to blue. Values are the means $\pm \mathrm{SD}(n=3)$. The experiments and following ones were carried out at room temperature and $85-90 \%$ relative humidity. The symbols * and ${ }^{* *}$ stand for significant difference between $\mathrm{C}_{2} \mathrm{H}_{4}$ and $\mathrm{C}_{2} \mathrm{H}_{4}-\mathrm{H}_{2} \mathrm{~S}$ at $p<0.05$ and $p<0.01$, respectively.

while the $\mathrm{a}^{*} / \mathrm{b}^{*}$ value of the $\mathrm{H}_{2} \mathrm{~S}$ plus ethylene treatment group remained at a lower level compared with ethylene treatment alone. Thus, additional $\mathrm{H}_{2} \mathrm{~S}$ treatment can slow the change of tomato color and delay the ripening of tomato fruit during post-harvest storage.

\section{$\mathrm{H}_{2} \mathrm{~S}$ Regulated the Metabolism of Chlorophyll, Anthocyanin, Flavonoids, Carotenoid, Total Phenols in Ethylene-Treated Tomato Fruits}

To further understand the mechanism of $\mathrm{H}_{2} \mathrm{~S}$ in alleviating color change of tomato fruits, we determined the contents of chlorophyll, anthocyanin, flavonoids, carotenoid, and total phenols. Total chlorophyll content was composed of chlorophyll a and chlorophyll b. As shown in Figure 2A, chlorophyll content in $\mathrm{C}_{2} \mathrm{H}_{4}$ fumigated tomato increased and reached the peak at the 2st day followed by a gradual decrease until 7th DAS. In contrast, chlorophyll increased and reached the highest level at 3 DAS with $\mathrm{C}_{2} \mathrm{H}_{4}-\mathrm{H}_{2} \mathrm{~S}$ treatment. Thus, chlorophyll sustained a higher level with $\mathrm{C}_{2} \mathrm{H}_{4}-\mathrm{H}_{2} \mathrm{~S}$ co-treatment than those of $\mathrm{C}_{2} \mathrm{H}_{4}$ treatment and reached a significant difference on 6 th and 7 th day $(p<0.01$ or $p<0.05)$. Meanwhile, the change trend of chlorophyll a and chlorophyll $b$ was the similar to total chlorophyll (Figures 2B,C). The contents of chlorophyll a and chlorophyll b in $\mathrm{C}_{2} \mathrm{H}_{4}$ treatment always sustained a significantly lower level than that of $\mathrm{C}_{2} \mathrm{H}_{4}-\mathrm{H}_{2} \mathrm{~S}$ co-treatment at 6 and 7 DAS $(p<0.01$ or $p<0.05)$.

Figure $3 \mathrm{~A}$ shows that anthocyanins increased and peaked at 4 DAS followed by a rapid decrease in $\mathrm{C}_{2} \mathrm{H}_{4}$ treatment, while in $\mathrm{C}_{2} \mathrm{H}_{4}-\mathrm{H}_{2} \mathrm{~S}$ co-treatment, anthocyanins increased steadily in the first 4 days and remained stable on the day 6 and day 7, and sustained a significantly higher level of anthocyanin at 6 and 7 DAS $(p<0.05)$.

Figure 3B showed the change of carotenoid content in tomato fruit during storage. The carotenoid content was increased firstly, then decreased and then increased with the extension of storage period in $\mathrm{C}_{2} \mathrm{H}_{4}-\mathrm{H}_{2} \mathrm{~S}$ and $\mathrm{C}_{2} \mathrm{H}_{4}$ treatment. Comparing with $\mathrm{C}_{2} \mathrm{H}_{4}$ treatment, carotenoid content remained at a higher level from day 2 to day 4 in $\mathrm{C}_{2} \mathrm{H}_{4}-\mathrm{H}_{2} \mathrm{~S}$ co-treatment.

As shown in Figure 3C, flavonoids increased gradually in both $\mathrm{C}_{2} \mathrm{H}_{4}$ and $\mathrm{C}_{2} \mathrm{H}_{4}-\mathrm{H}_{2} \mathrm{~S}$ treatments until 4 DAS followed by a decrease. The content of flavonoids in the $\mathrm{C}_{2} \mathrm{H}_{4}$ treatment increased and reached the highest level on the day 3 , then began to decrease until 7 DAS. The content of flavonoids in the $\mathrm{C}_{2} \mathrm{H}_{4}$ $\mathrm{H}_{2} \mathrm{~S}$ treatment decreased from the 2 nd day, and was significantly lower than the $\mathrm{C}_{2} \mathrm{H}_{4}$ treatment at 3 and 4 DAS $(p<0.01)$.

In general, Figure 3D showed that total phenols increased steadily during the early storage time. It increased at first, but decreased at 3 DAS, then gradually increased and then tended to be stable in $\mathrm{C}_{2} \mathrm{H}_{4}$ treatment. Similar trends were observed in $\mathrm{C}_{2} \mathrm{H}_{4}-\mathrm{H}_{2} \mathrm{~S}$ co-treatment, but decreased at 4 DAS.

\section{Changes of Amylase Activity, Protease Activity, Contents of Starch and Soluble Protein Between $\mathrm{C}_{2} \mathrm{H}_{4}-\mathrm{H}_{2} \mathrm{~S}$ and $\mathrm{C}_{2} \mathrm{H}_{4}$} Treatment

To compare the effects of $\mathrm{H}_{2} \mathrm{~S}$ treatment on $\mathrm{C}_{2} \mathrm{H}_{4}$-induced tomato fruit quality, amylase activity, protease activity, the content of starch and soluble protein were measured. Figure 4A showed the changes of amylase activity in tomato fruit. It 

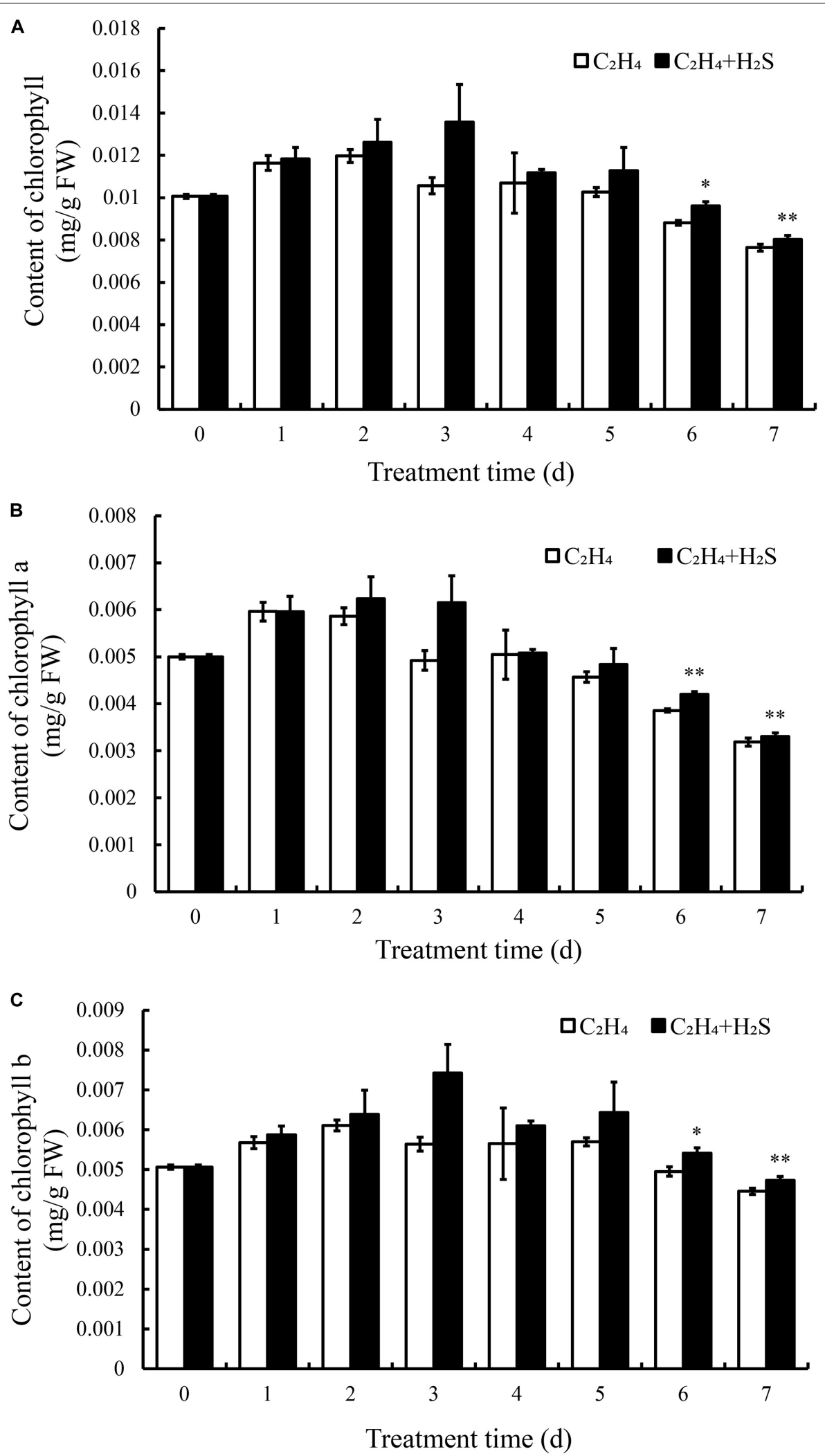

FIGURE 2 | Effects of $\mathrm{C}_{2} \mathrm{H}_{4}$ and $\mathrm{C}_{2} \mathrm{H}_{4}-\mathrm{H}_{2} \mathrm{~S}$ on the contents of total chlorophyll (A), chlorophyll a (B), chlorophyll b (C) in post-harvest tomato. Data are presented as means $\pm \mathrm{SD}(n=3)$. ${ }^{*}$ and ${ }^{* *}$ in this figure and following ones stand for a significant difference between $\mathrm{C}_{2} \mathrm{H}_{4}$ treatment and $\mathrm{C}_{2} \mathrm{H}_{4}-\mathrm{H}_{2} \mathrm{~S}$ co-treatment at $p<0.05$ and $p<0.01$, respectively. 

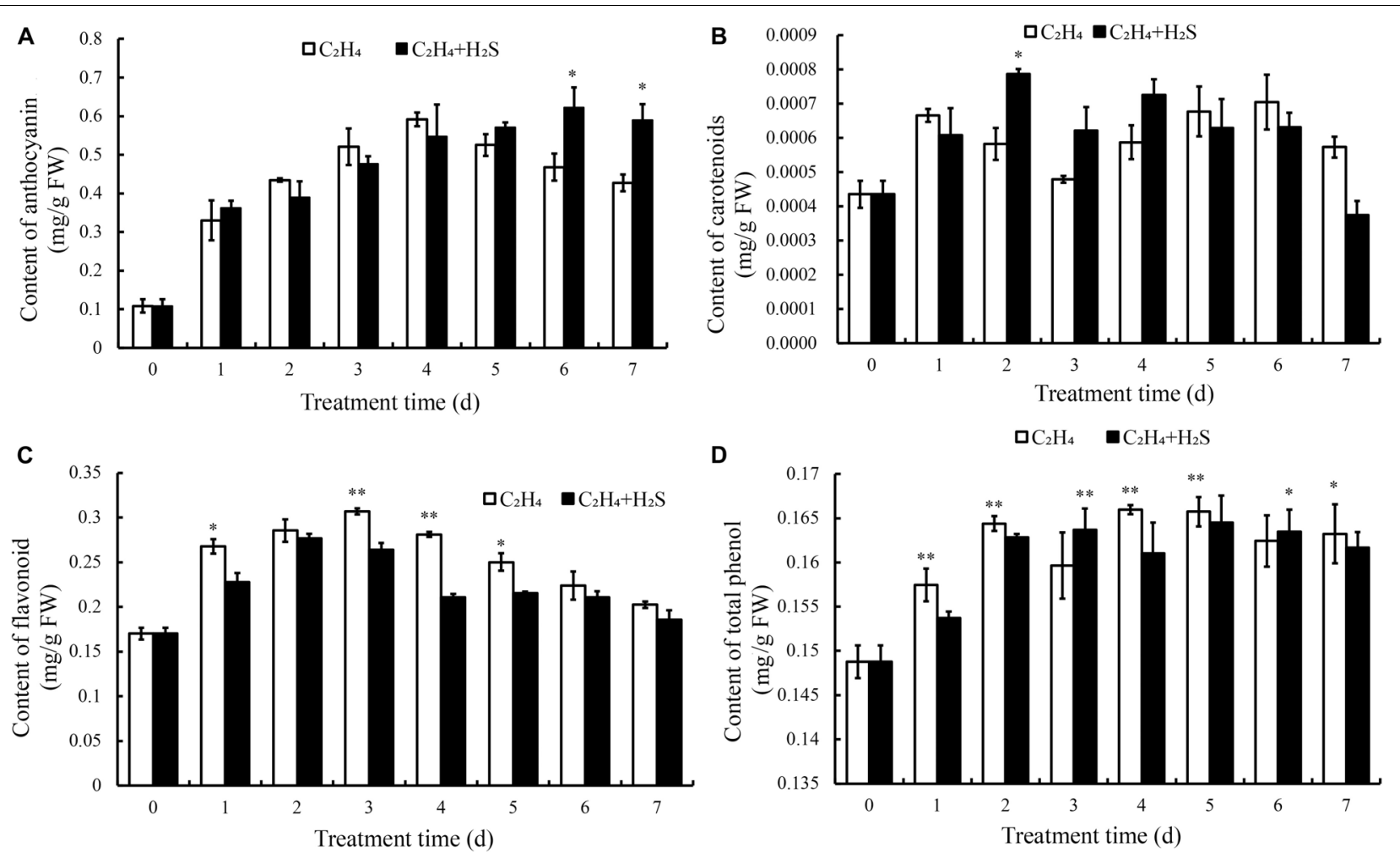

FIGURE 3 | Effect of $\mathrm{C}_{2} \mathrm{H}_{4}$ and $\mathrm{C}_{2} \mathrm{H}_{4}-\mathrm{H}_{2} \mathrm{~S}$ on the contents of anthocyanin (A), flavonoids (B), carotenoid (C), total phenols (D). Data are presented as means $\pm \mathrm{SD}$ $(n=3)$. The symbols * and ** stand for significant difference between $\mathrm{C}_{2} \mathrm{H}_{4}$ and $\mathrm{C}_{2} \mathrm{H}_{4}-\mathrm{H}_{2} \mathrm{~S}$ at $p<0.05$ and $p<0.01$, respectively.

increased and reached the highest level at 3 DAS and then decreased with the storage time in $\mathrm{C}_{2} \mathrm{H}_{4}$ and $\mathrm{C}_{2} \mathrm{H}_{4}-\mathrm{H}_{2} \mathrm{~S}$ cotreatment. As shown in Figure 4B, protease activity was steadily increased in both treatments during the storage. $\mathrm{C}_{2} \mathrm{H}_{4}-\mathrm{H}_{2} \mathrm{~S}$ cotreatment maintained significant lower level of protease activity from 3 to 7 DAS except day 5 compared with $\mathrm{C}_{2} \mathrm{H}_{4}$ treatment.

The change of starch content was shown in Figure 4C. In general, with the extension of storage period, the starch content decreased rapidly. The content of starch in $\mathrm{C}_{2} \mathrm{H}_{4}$ $\mathrm{H}_{2} \mathrm{~S}$ co-treatment decreased relatively slowly, and maintained a significantly higher level on 4 DAS $(p<0.05)$. The change of soluble protein was shown in Figure 4D. The content of soluble protein increased in the first 3 days of the two treatments. Compared with the $\mathrm{C}_{2} \mathrm{H}_{4}$ treatment, $\mathrm{C}_{2} \mathrm{H}_{4}-\mathrm{H}_{2} \mathrm{~S}$ co-treatment sustained a significantly higher level of soluble protein content from day 3 to day 7 ( $p<0.01$ or $p<0.05)$, suggesting that $\mathrm{H}_{2} \mathrm{~S}$ could alleviate the degradation of protein in tomato fruit during storage.

\section{Effect of $\mathrm{H}_{2} \mathrm{~S}$ on the Contents of Reducing Sugar, Titratable Acid (TA) and Ascorbic Acid, the Ratio of the Reducing Sugar to Titratable Acids}

The change of reducing sugar in tomato fruit is shown in Figure 5A. The contents of reducing sugar showed a downward trend in the two treatment groups. Reducing sugar contents in the $\mathrm{C}_{2} \mathrm{H}_{4}-\mathrm{H}_{2} \mathrm{~S}$ co-treatment had higher level from 2 to 7 days than that those of $\mathrm{C}_{2} \mathrm{H}_{4}$ treatment. Figure 5B showed that TA content decreased gradually in the two treatments. The $\mathrm{C}_{2} \mathrm{H}_{4}$ $\mathrm{H}_{2} \mathrm{~S}$ co-treatment sustained a significantly lower level of TA than $\mathrm{C}_{2} \mathrm{H}_{4}$ treatment from 1 to 6 days $(p<0.01$ or $p<0.05)$.

The sweetness and acidity of the fruit are the important indicators for evaluating the flavor. As shown in Figure 5C, in $\mathrm{C}_{2} \mathrm{H}_{4}$ treatment, the ratio decreased slightly till 4 DAS, then increased gradually. Meanwhile, the ratio sustained a higher level in the $\mathrm{C}_{2} \mathrm{H}_{4}-\mathrm{H}_{2} \mathrm{~S}$ co-treatment on 2, 3, 6 DAS.

Ascorbic acid is an important nutrient for tomato fruits. As shown in Figure 5D, ascorbic acid contents in both treatments increased gradually and peaked on 4 DAS followed by a decrease. However, there is no significant differences between the two treatments.

\section{Role of $\mathrm{H}_{2} \mathrm{~S}$ on the Transcription of Metabolism and Ripening Related Genes}

As shown in Figure $\mathbf{6 A}$, the transcript level of beta-amylase encoding gene $B A M 3$ increased gradually till day 5 in ethylenetreated tomatoes, whereas ethylene $+\mathrm{H}_{2} \mathrm{~S}$ treatment induced the expression of $B A M 3$ on day 1 and reduced the expression on day 5. Figures 6B,C showed the changes of UDP glucose: flavonoid-3-O-glucosyltransferase encoding genes UFGT73 and UFGT5 during tomato storage, respectively. The expression of UFGT73 fluctuated and $\mathrm{H}_{2} \mathrm{~S}$ induced lower transcript level on 


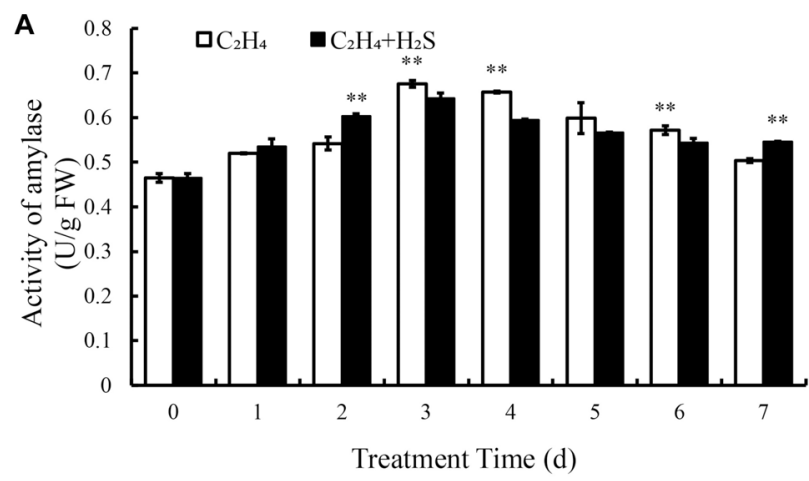

C

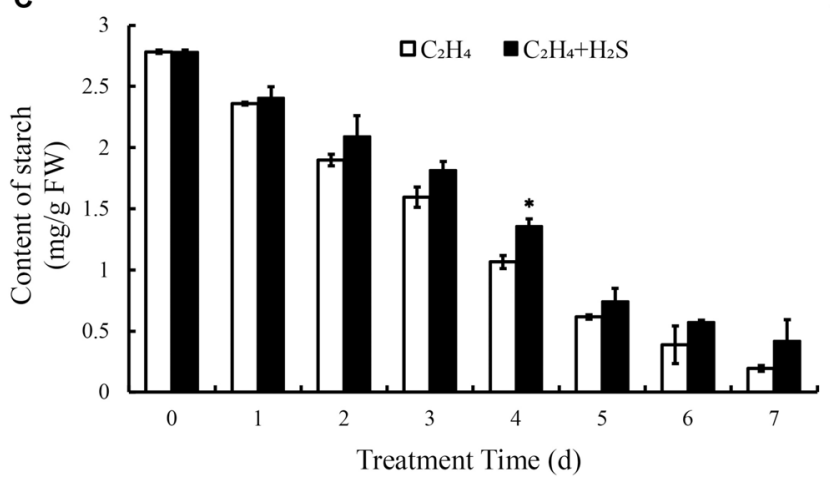

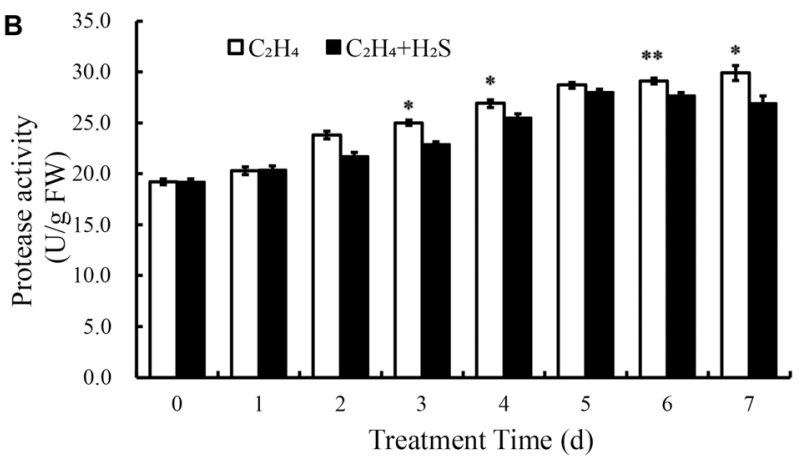

D

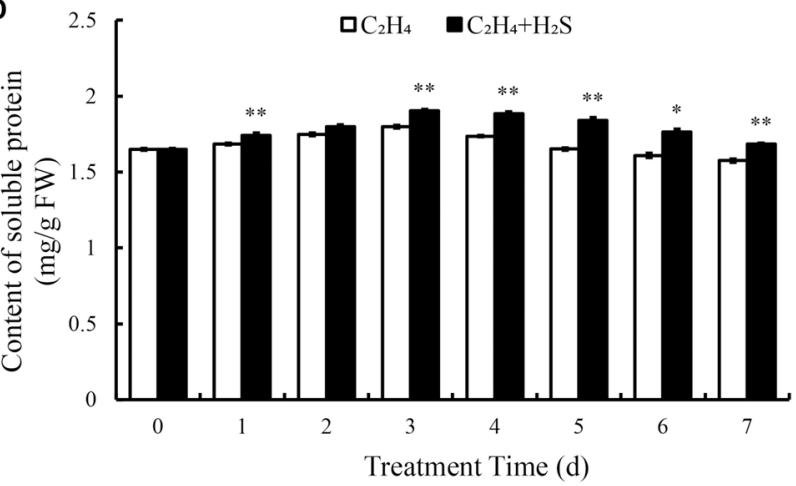

FIGURE 4 | Effect of $\mathrm{C}_{2} \mathrm{H}_{4}$ and $\mathrm{C}_{2} \mathrm{H}_{4}-\mathrm{H}_{2} \mathrm{~S}$ on activity of amylase (A), protease activity (B), content of starch (C) and content of soluble protein (D). Data are presented as means $\pm \mathrm{SD}(n=3)$. The symbols * and ** stand for significant difference between $\mathrm{C}_{2} \mathrm{H}_{4}$ and $\mathrm{C}_{2} \mathrm{H}_{4}-\mathrm{H}_{2} \mathrm{~S}$ at $p<0.05$ and $p<0.01$, respectively.

day 5. However, $\mathrm{H}_{2} \mathrm{~S}$ enhanced the expression of UFGT5 on day 1 while attenuated the expression on day 5 in comparison to $\mathrm{C}_{2} \mathrm{H}_{4}$ treatment. The transcription of several ripening related transcription factor ERF003, DOF22 and WRKY51 were also analyzed and shown in Figures 6D-F, respectively. Generally, ERF003 expression showed an increasing trend during storage in $\mathrm{C}_{2} \mathrm{H}_{4}$ group. The increase of ERF003 expression on day 5 was significantly inhibited by additional $\mathrm{H}_{2} \mathrm{~S}$ treatment, though $\mathrm{H}_{2} \mathrm{~S}$ induced a mild increase of ERF003 expression on days 1 and 3. Besides, $\mathrm{C}_{2} \mathrm{H}_{4}$ treatment induced higher expression of DOF22 on day 1 followed by a decrease, whereas the increase in DOF22 expression was significantly attenuated by additional $\mathrm{H}_{2} \mathrm{~S}$ treatment. An increase in WRKY51 expression was observed in both treatments on day 1 . Additional $\mathrm{H}_{2} \mathrm{~S}$ was found to inhibit the expression of WRKY51 on day 5 and reverse trend was observed on day 3. Thus, the modulation of metabolism and ripening related gene expression by $\mathrm{H}_{2} \mathrm{~S}$ may contribute to changes in nutrient metabolism.

\section{PCA Analysis, Correlation Analysis, and Heatmap of the Changes in Bioactive Substances in Tomato Fruits}

Principal component analysis analysis was performed in Table $\mathbf{1}$ and shown in Figure 7. The contribution rate of PC1, PC2, and PC3 was 47.64, 38.42, and 6.3\%, respectively. In PC1, TA, protease activity and starch were the main factors. In PC2, flavonoid, chlorophyll b, and amylase activity were the main factors, while, in PC3, ascorbic acid was the main factor.

Correlation analysis of various bioactive substances are shown in Figure 8A. Starch and reducing sugar showed a significant negative correlation with ascorbic acid, total phenols, and anthocyanin. Meanwhile, starch and reducing sugar had a significant positive correlation with titratable acid and chlorophyll. Chlorophyll (including chlorophyll a, chlorophyll b) showed a positive correlation with flavonoids, carotenoids, TA, whereas had a negatively correlation with anthocyanins. From the Figure 8A, it can be clearly seen that carotenoids have significant color differences in the $\mathrm{C}_{2} \mathrm{H}_{4}$ treatment and $\mathrm{C}_{2} \mathrm{H}_{4}+\mathrm{H}_{2} \mathrm{~S}$ co-treatment, indicating that under the conditions of ethylene fumigation, $\mathrm{H}_{2} \mathrm{~S}$ could significantly enhance correlation of carotenoids with other indicators.

As shown in Figure $\mathbf{8 B}$, in general, protease activity, anthocyanins, total phenols, ascorbic acid were gradually increased with the storage time; starch, reducing sugar, titratable acid were gradually decreased. Content of soluble protein, activity of amylase, contents of chlorophyll $b$ and flavonoids were increased firstly, reached the highest level on day 2 or day 3, and then gradually decreased with the storage time. Comparing with $\mathrm{C}_{2} \mathrm{H}_{4}$ treatment, the content of reducing sugar, content of chlorophyll b, content of chlorophyll reached the highest level in the $\mathrm{C}_{2} \mathrm{H}_{4}+\mathrm{H}_{2} \mathrm{~S}$ co-treatment later, indicating that under the conditions of ethylene application, $\mathrm{H}_{2} \mathrm{~S}$ could slow the degradation of reducing sugar and chlorophyll. 

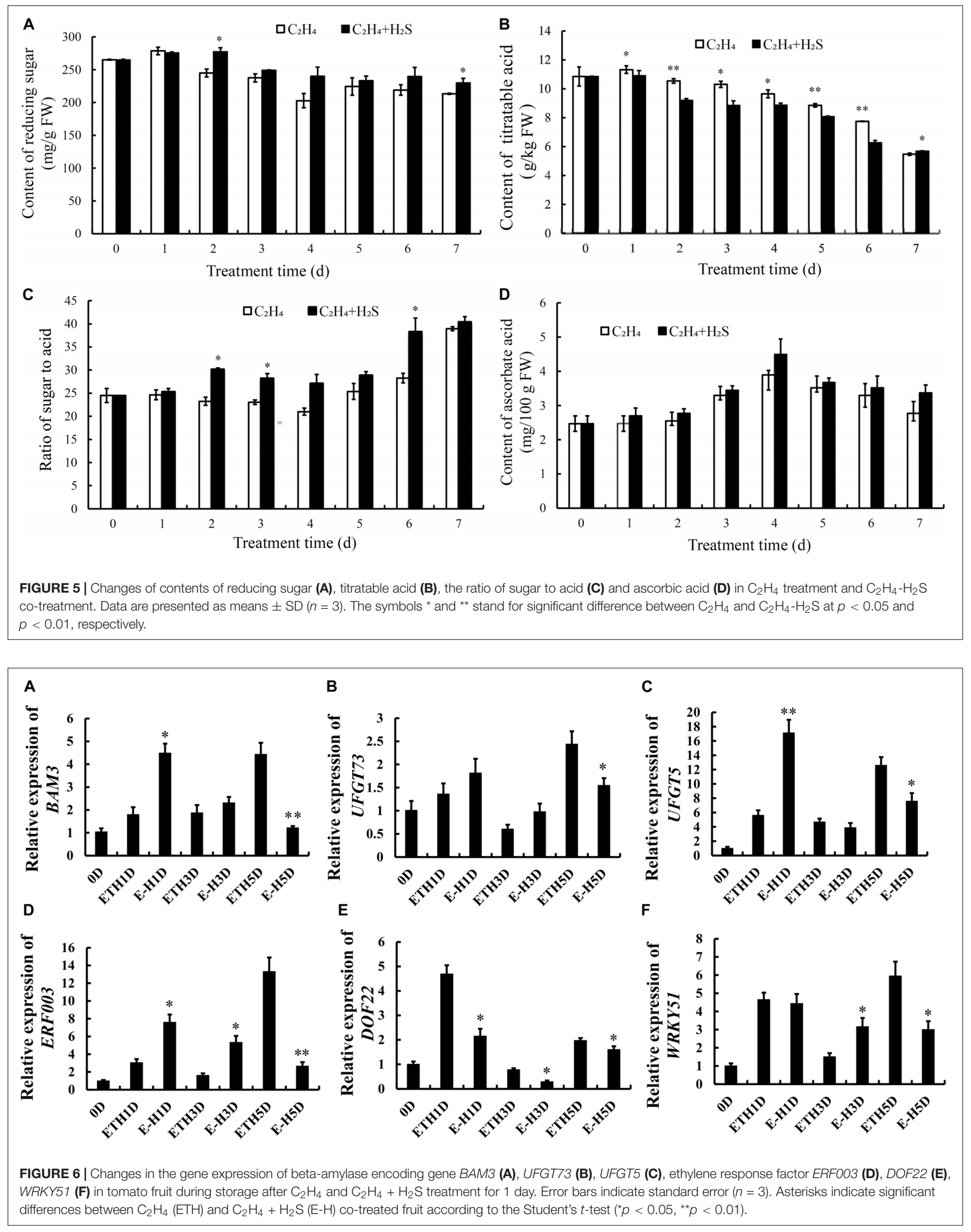
TABLE 1 | The factors score of all the metabolites by principal component analysis in tomato fruits.

\begin{tabular}{|c|c|c|c|}
\hline Metabolites & Component 1 & Component 2 & Component 3 \\
\hline $\begin{array}{l}\text { Content of titratable acid } \\
\left(\mathrm{C}_{2} \mathrm{H}_{4}+\mathrm{H}_{2} \mathrm{~S}\right)\end{array}$ & 0.975 & 0.18 & \\
\hline Protease activity $\left(\mathrm{C}_{2} \mathrm{H}_{4}\right)$ & -0.95 & & 0.272 \\
\hline $\begin{array}{l}\text { Content of chlorophyll b } \\
\left(\mathrm{C}_{2} \mathrm{H}_{4}+\mathrm{H}_{2} \mathrm{~S}\right)\end{array}$ & 0.948 & 0.101 & -0.25 \\
\hline $\begin{array}{l}\text { Content of starch } \\
\left(\mathrm{C}_{2} \mathrm{H}_{4}+\mathrm{H}_{2} \mathrm{~S}\right)\end{array}$ & 0.939 & 0.156 & -0.228 \\
\hline $\begin{array}{l}\text { Content of titratable acid } \\
\left(\mathrm{C}_{2} \mathrm{H}_{4}\right)\end{array}$ & 0.895 & 0.427 & \\
\hline $\begin{array}{l}\text { Content of Anthocyanidin } \\
\left(\mathrm{C}_{2} \mathrm{H}_{4}+\mathrm{H}_{2} \mathrm{~S}\right)\end{array}$ & -0.88 & 0.191 & 0.276 \\
\hline Protease activity $\left(\mathrm{C}_{2} \mathrm{H}_{4}+\mathrm{H}_{2} \mathrm{~S}\right)$ & -0.871 & & 0.376 \\
\hline $\begin{array}{l}\text { Content of total phenol } \\
\left(\mathrm{C}_{2} \mathrm{H}_{4}+\mathrm{H}_{2} \mathrm{~S}\right)\end{array}$ & -0.806 & 0.535 & 0.133 \\
\hline Content of chlorophyll a $\left(\mathrm{C}_{2} \mathrm{H}_{4}\right)$ & 0.796 & 0.522 & -0.109 \\
\hline $\begin{array}{l}\text { Content of reducing sugar } \\
\left(\mathrm{C}_{2} \mathrm{H}_{4}\right)\end{array}$ & 0.783 & & -0.537 \\
\hline $\begin{array}{l}\text { Content of reducing sugar } \\
\left(\mathrm{C}_{2} \mathrm{H}_{4}+\mathrm{H}_{2} \mathrm{~S}\right)\end{array}$ & 0.776 & 0.252 & -0.529 \\
\hline Content of total phenol $\left(\mathrm{C}_{2} \mathrm{H}_{4}\right)$ & -0.697 & 0.427 & 0.237 \\
\hline Content of chlorophyll $\left(\mathrm{C}_{2} \mathrm{H}_{4}\right)$ & 0.69 & 0.645 & \\
\hline $\begin{array}{l}\text { Content of Anthocyanidin } \\
\left(\mathrm{C}_{2} \mathrm{H}_{4}\right)\end{array}$ & -0.633 & 0.581 & 0.445 \\
\hline $\begin{array}{l}\text { Content of flavonoid } \\
\left(\mathrm{C}_{2} \mathrm{H}_{4}+\mathrm{H}_{2} \mathrm{~S}\right)\end{array}$ & & 0.952 & -0.274 \\
\hline Content of flavonoid $\left(\mathrm{C}_{2} \mathrm{H}_{4}\right)$ & & 0.95 & 0.143 \\
\hline $\begin{array}{l}\text { Content of chlorophyll b } \\
\left(\mathrm{C}_{2} \mathrm{H}_{4}+\mathrm{H}_{2} \mathrm{~S}\right)\end{array}$ & & 0.93 & 0.195 \\
\hline $\begin{array}{l}\text { Activity of amylase } \\
\left(\mathrm{C}_{2} \mathrm{H}_{4}+\mathrm{H}_{2} \mathrm{~S}\right)\end{array}$ & -0.37 & 0.904 & 0.15 \\
\hline $\begin{array}{l}\text { Content of chlorophyll } \\
\left(\mathrm{C}_{2} \mathrm{H}_{4}+\mathrm{H}_{2} \mathrm{~S}\right)\end{array}$ & 0.411 & 0.895 & \\
\hline $\begin{array}{l}\text { Content of soluble protein } \\
\left(\mathrm{C}_{2} \mathrm{H}_{4}\right)\end{array}$ & 0.378 & 0.876 & 0.172 \\
\hline $\begin{array}{l}\text { Content of soluble protein } \\
\left(\mathrm{C}_{2} \mathrm{H}_{4}+\mathrm{H}_{2} \mathrm{~S}\right)\end{array}$ & -0.169 & 0.83 & 0.522 \\
\hline $\begin{array}{l}\text { Content of chlorophyll b } \\
\left(\mathrm{C}_{2} \mathrm{H}_{4}\right)\end{array}$ & 0.436 & 0.798 & \\
\hline $\begin{array}{l}\text { Content of carotenoids } \\
\left(\mathrm{C}_{2} \mathrm{H}_{4}+\mathrm{H}_{2} \mathrm{~S}\right)\end{array}$ & 0.111 & 0.767 & 0.191 \\
\hline $\begin{array}{l}\text { Content of chlorophyll a } \\
\left(\mathrm{C}_{2} \mathrm{H}_{4}+\mathrm{H}_{2} \mathrm{~S}\right)\end{array}$ & 0.633 & 0.761 & -0.124 \\
\hline Activity of amylase $\left(\mathrm{C}_{2} \mathrm{H}_{4}\right)$ & -0.268 & 0.702 & 0.631 \\
\hline $\begin{array}{l}\text { Content of ascorbic acid } \\
\left(\mathrm{C}_{2} \mathrm{H}_{4}\right)\end{array}$ & -0.408 & 0.259 & 0.865 \\
\hline $\begin{array}{l}\text { Content of ascorbic acid } \\
\left(\mathrm{C}_{2} \mathrm{H}_{4}+\mathrm{H}_{2} \mathrm{~S}\right)\end{array}$ & -0.516 & 0.19 & 0.81 \\
\hline Content of carotenoids $\left(\mathrm{C}_{2} \mathrm{H}_{4}\right)$ & -0.39 & & \\
\hline
\end{tabular}

\section{DISCUSSION}

Ethylene, a gaseous hormone with a simple structure, regulates many processes of plant growth and development, including root hair formation, flowering, the senescence and abscission of fruit and leaf, etc. (Dugardeyn and Van Der Straeten, 2008). In the ripening of climacteric fruits, ethylene biosynthesis system 2 called "autocatalytic synthesis" accounts for massive ethylene production (Bapat et al., 2010). Besides, exogenous application of ethylene will hasten ripening process by initiating a signaling

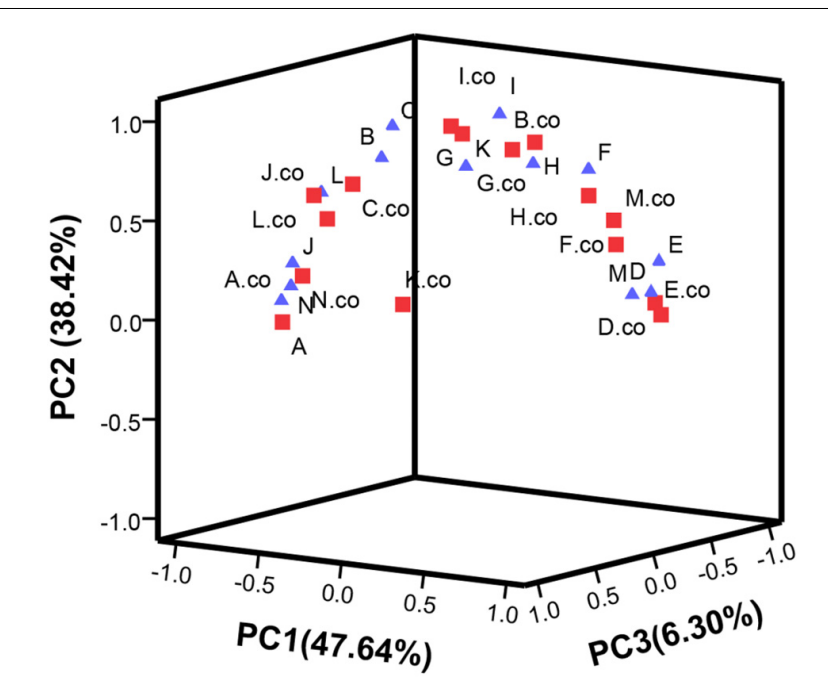

FIGURE 7 | Principal component analysis the main metabolites of post-harvest tomato fruits. PC1 PC3 were respectively represented the contribution rate of principal components. $\mathrm{C}_{2} \mathrm{H}_{4}$ treatment groups were marked as "co" and square, $\mathrm{C}_{2} \mathrm{H}_{4}-\mathrm{H}_{2} \mathrm{~S}$ treatment groups were marked by triangle. Metabolites are expressed by $A \sim N$. (A) Protease activity, (B) Soluble protein, (C) Activity of amylase, (D) Starch content, (E) Reducing sugar, (F) Chlorophyll a, (G) Chlorophyll b, (H) Chlorophyll, (I) flavonoid, (J) anthocyanins, (K) Carotenoids, (L) Total phenol, (M) Titratable acid, (N) Ascorbic acid. Data represent the normalized mean values of three independent biological replicates.

cascade. Researchers have developed different means to slowing down post-ripening process in fleshy fruit by genetic engineering or ethylene inhibitor (Bapat et al., 2010). $\mathrm{H}_{2} \mathrm{~S}$, with the odor of rotten eggs, has been found to participate in varied physiological processes in both animal and plant after the discovery of the physiological roles of nitric oxide (NO) and carbon monoxide (CO) (Rochette and Vergely, 2008). In plants, $\mathrm{H}_{2} \mathrm{~S}$ has been revealed as a crucial regulator in multiple physiological processes, including seed germination, root morphogenesis, photosynthesis, and flower senescence (Zhang et al., 2008, 2009, 2010, 2011). Recently, it was reported that $\mathrm{H}_{2} \mathrm{~S}$ could induce changes in transcriptome and inhibit ethylene production, delay the ripening and senescence of kiwifruits and maintain higher contents of nutrients during storage (Zhu et al., 2014; Lin et al., 2020). Moreover, $\mathrm{H}_{2} \mathrm{~S}$ delayed the loss of chlorophyll and respiration in leafy vegetables by inhibiting ethylene production and action (Ubeed et al., 2017).

In this study, the antagonizing effect of $\mathrm{C}_{2} \mathrm{H}_{4}$ and $\mathrm{H}_{2} \mathrm{~S}$ on various bioactive substances were estimated in tomato fruits during the post-harvest storage. Color is an important characteristic that reflects the ripening stage of tomato fruit. It has shown that the color change of fruits is closely related to chlorophyll, carotenoids and anthocyanins. In our experiments, as shown in Figures 2A-C, comparing with $\mathrm{C}_{2} \mathrm{H}_{4}$ treatment, $\mathrm{C}_{2} \mathrm{H}_{4}-\mathrm{H}_{2} \mathrm{~S}$ co-treatment sustained a higher level of chlorophyll and anthocyanin during storage period, but remained a lower level of flavonoid. The similar phenomenon was reported in broccoli, water spinach as well as other 


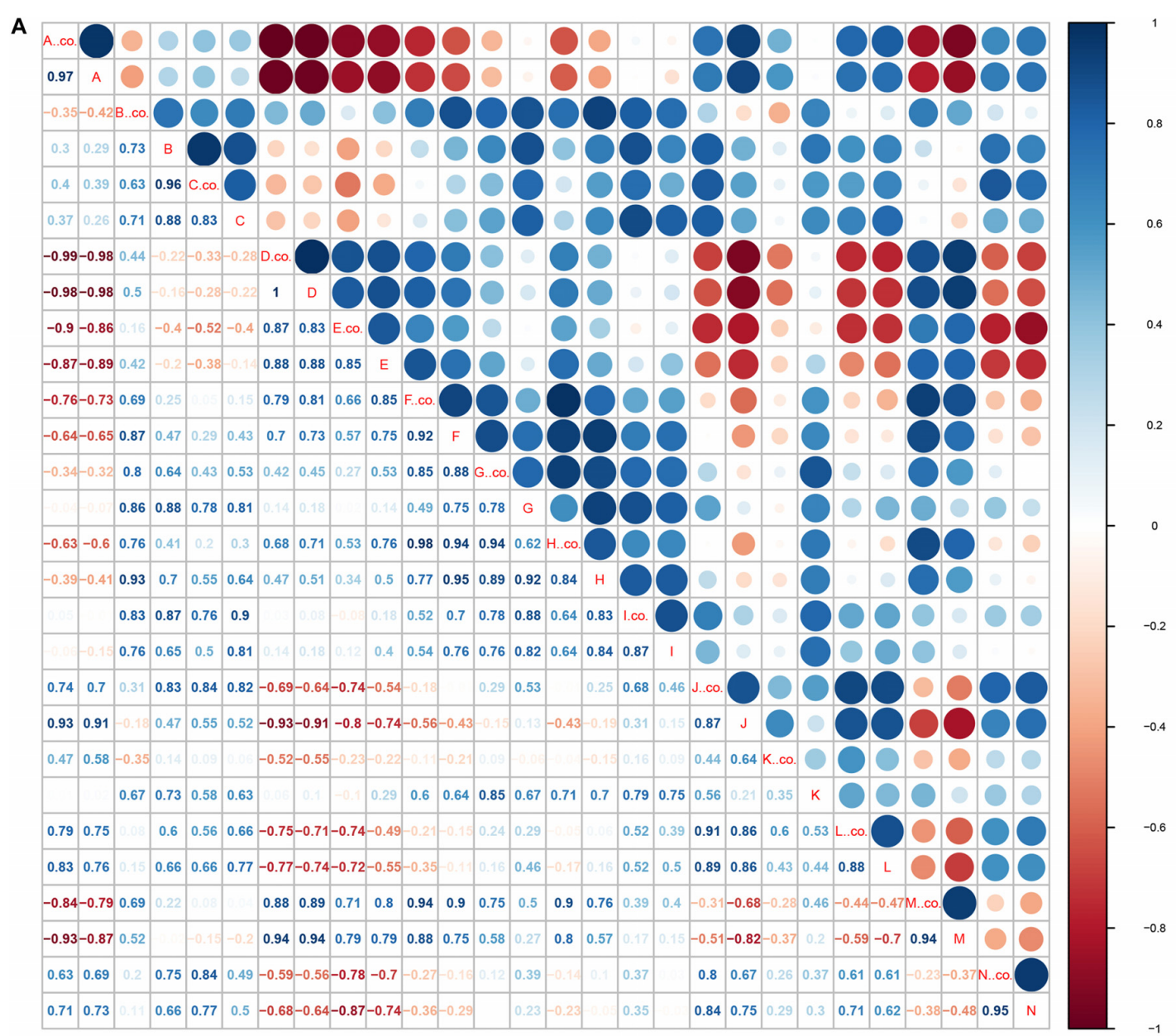

B

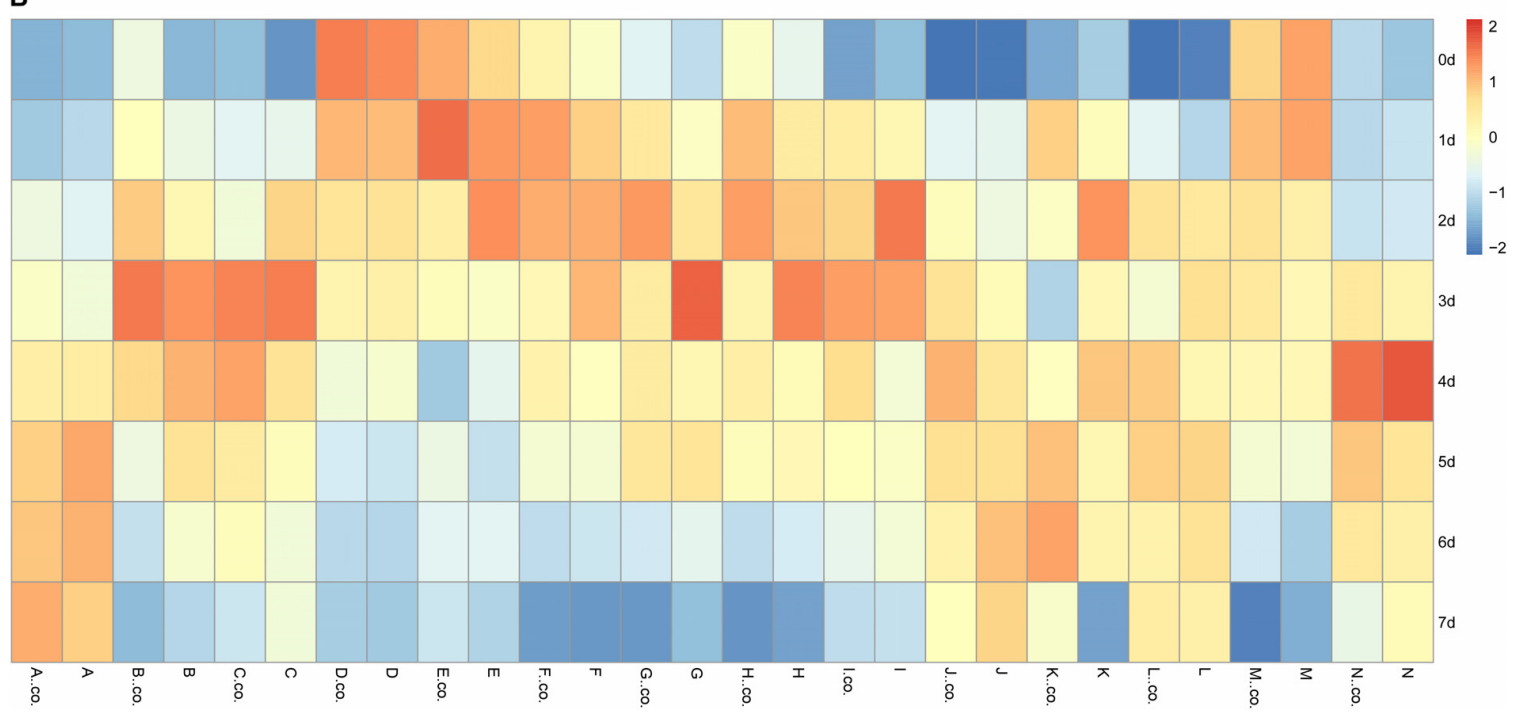

FIGURE 8 | Correlation analysis (A) and the heatmap (B) among the parameters of bioactive compounds. (A) The correlation analysis the relationship among bioactive compounds. Correlation coefficient was analyzed using $R$ scripts. (B) The heatmap analyzed the change of bioactive compounds in the storage periods of tomato fruit. co- indicated control group $\left(\mathrm{C}_{2} \mathrm{H}_{4}\right)$, co-treatment group no marked. (A) Protease activity, (B) Soluble protein, (C) Activity of amylase, (D) Starch content, (E) Reducing sugar, (F) Chlorophyll a, (G) Chlorophyll b, (H) Chlorophyll, (I) flavonoid, (J) anthocyanins, (K) Carotenoids, (L) Total phenol, (M) Titratable acid, (N) Ascorbic acid. 
living plants (Li et al., 2014; Hu et al., 2015). Correlation analysis showed that chlorophyll has a positive correlation with flavonoids, carotenoids, however, has a negative correlated with anthocyanins (Figure 8A). The shift of the pigments reflects the tomato ripening stage, which provides a good basis for assessing fruit ripening. However, $\mathrm{H}_{2} \mathrm{~S}$ could delay the color changes of tomato and slow the ripening process of tomato fruit. Moreover, $\mathrm{H}_{2} \mathrm{~S}$ was closely associated with chlorophyll degradation and anthocyanin biosynthesis. It was reported chlorophyllase (CHL) and pheophytinase (PPH) are required in chlorophyll degradation (Schelbert et al., 2009). Moreover, UDP glucose: flavonoid-3-O-glucosyltransferase (UFGT) catalyzes anthocyanidins to glucosylated anthocyanins in litchi during fruit coloration (Zhao et al., 2012). In the present research, we found that $\mathrm{H}_{2} \mathrm{~S}$ up-regulated the expression of UFGT5 in the early stage of storage which may contribute to accumulated anthocyanin in $\mathrm{H}_{2} \mathrm{~S}$-treated tomato fruits. However, the regulating role of $\mathrm{H}_{2} \mathrm{~S}$ on $\mathrm{CHL} / \mathrm{PPH}$ in delaying ripening and senescence still needs further study.

$\mathrm{H}_{2} \mathrm{~S}$ can maintain the well-appearance of post-harvest broccoli and meanwhile higher nutrient contents, such as, ascorbic acid, reducing sugar and soluble protein than $\mathrm{C}_{2} \mathrm{H}_{4}$ treatment (Li et al., 2014). In the present study, ascorbic acid, reducing sugar, soluble protein and starch were also determined in tomato during post-harvest storage. As shown in Figures 4C,D, 5A,D, tomato fruit with $\mathrm{C}_{2} \mathrm{H}_{4}-\mathrm{H}_{2} \mathrm{~S}$ cotreatment could sustain higher level of ascorbic acid, reducing sugar and soluble protein, starch than $\mathrm{C}_{2} \mathrm{H}_{4}$ treatment. In PCA analysis, soluble protein, starch and TA, amylase activity and ascorbic acid were the main factors, which could significantly affect tomato fruit quality during post-harvest storage. Thus, $\mathrm{H}_{2} \mathrm{~S}$ can alleviate the decreases in ascorbic acid, reducing sugar, soluble protein and starch, strongly supporting the role of $\mathrm{H}_{2} \mathrm{~S}$ in alleviating the senescence of tomato fruits. RT-qPCR result showed that the expression of beta-amylase encoding gene BAM3 at late storage stage was inhibited by $\mathrm{H}_{2} \mathrm{~S}$ treatment. Recently, it is reported that starch degradation was regulated by an ethylene responsive $\mathrm{C} 2 \mathrm{H} 2$-type zinc finger transcription factor AdDof3 in kiwifruit ripening and senescence (Zhang et al., 2018), thereby providing a cue to research the molecular mechanism of $\mathrm{H}_{2} \mathrm{~S}$ in tomato fruit quality during storage.

Sugar content was the best criteria for evaluating the maturity of the fruit. The ratio of sugar/acid is an index which affects fruit flavor quality. In this study, $\mathrm{H}_{2} \mathrm{~S}$ could maintain higher level of reducing sugar from 2 to 7 DAS and ascorbic acid contents than those of $\mathrm{C}_{2} \mathrm{H}_{4}$ treatment (Figures 5A,D). It was showed that reducing sugar has an obviously negative correlation with ascorbic acid (Figure 8A). Meanwhile, phenolic compounds are second metabolites in many fruits and well-known for their antioxidant potential, and their role in prevention of heart diseases, inflammation, and reducing the incidence of cancer and diabetes (Kaur and Kapoor, 2001). Previous report suggested a strong correlation between total antioxidant activity and total phenolic content (Macoris et al., 2012). The total phenols have a negative correlation with reducing sugar (Figure 8A). The results showed that $\mathrm{H}_{2} \mathrm{~S}$ can effectively inhibit the decrease of reducing sugar and ascorbic acid, indicating that $\mathrm{H}_{2} \mathrm{~S}$ contributed to improved antioxidant capacity to extend postharvest storage period.

In our study, we demonstrated the indispensable role of $\mathrm{H}_{2} \mathrm{~S}$ in delaying ripening and senescence of tomato fruits during the storage period. Our results showed $\mathrm{H}_{2} \mathrm{~S}$ could maintained higher levels of metabolites, such as chlorophyll, starch, soluble protein and ascorbic acid. It implied that $\mathrm{H}_{2} \mathrm{~S}$ might be an endogenous signal which regulated the ripening and senescence of post-harvest fruits by repression of the effect of ethylene.

\section{DATA AVAILABILITY STATEMENT}

The raw data supporting the conclusions of this article will be made available by the authors, without undue reservation, to any qualified researcher.

\section{AUTHOR CONTRIBUTIONS}

G-FY, CL, K-KS, K-DH, and HZ conceived and designed the experiments. G-FY, CL, K-KS, G-GH, Z-QH, PJ, and JT performed the experiments. G-FY, CL, FY, and L-YH analyzed the data. G-FY, CL, PJ, and K-DH wrote the manuscript. G-FY, $\mathrm{K}-\mathrm{DH}$, and $\mathrm{HZ}$ interpreted the data and revised the manuscript.

\section{FUNDING}

This work was supported by the National Natural Science Foundation of China (31970312, 31970200, 31901993, 31670278, and 31872078), the Natural Science Foundations of Anhui Province (1908085MC72), the Key Research and Development Program of Anhui Province (201904a06020031), and the Earmarked Fund for the China Agriculture Research System (CARS-10-B1).

\section{SUPPLEMENTARY MATERIAL}

The Supplementary Material for this article can be found online at: https://www.frontiersin.org/articles/10.3389/fpls.2020.00584/ full\#supplementary-material

\section{REFERENCES}

Bapat, V. A., Trivedi, P. K., Ghosh, A., Sane, V. A., Ganapathi, T. R., and Nath, P. (2010). Ripening of fleshy fruit: molecular insight and the role of ethylene. Biotechnol Adv. 28, 94-107. doi: 10.1016/j.biotechadv.2009.10.002

Bradford, M. M. (1976). A rapid and sensitive method for the quantitation of microgram quantities of protein utilizing the principle of protein-dye binding. Anal. Biochem. 72, 248-254. doi: 10.1006/abio.1976 9999

Bureau, S., Ruiz, D., Reich, M., Gouble, B., Bertrand, D., Audergon, J. M., et al. (2009). Application of ATR-FTIR for a rapid and simultaneous determination of sugars and organic acids in apricot fruit. Food Chem. 115, 1133-1140.

Chen, Z., Qin, C., Wang, M., Liao, F., Liao, Q., Liu, X., et al. (2019). Ethylenemediated improvement in sucrose accumulation in ripening sugarcane involves 
increased sink strength. BMC Plant Biol. 19:285. doi: 10.1186/s12870-0191882-z

Dubois, M., Van den Broeck, L., and Inzé, D. (2018). The pivotal role of ethylene in plant growth. Trends Plant Sci. 23, 311-323. doi: 10.1016/j.tplants.2018.01.003

Dugardeyn, J., and Van Der Straeten, D. (2008). Ethylene: fine-tuning plant growth and development by stimulation and inhibition of elongation. Plant Sci. 175, 59-70.

Gapper, N. E., McQuinn, R. P., and Giovannoni, J. J. (2013). Molecular and genetic regulation of fruit ripening. Plant Mol. Biol. 82, 575-591. doi: 10.1007/s11103013-0050-3

Giovannetti, M., Avio, L., Barale, R., Ceccarelli, N., Cristofani, R., Iezzi, A., et al. (2012). Nutraceutical value and safety of tomato fruits produced by mycorrhizal plants. Br. J. Nutr. 107, 242-251. doi: 10.1017/S000711451100290X

Guo, J., Wang, S., Yu, X., Dong, R., Li, Y., Mei, X., et al. (2018). Polyamines regulate strawberry fruit ripening by abscisic acid, auxin, and ethylene. Plant Physiol. 177, 339-351. doi: 10.1104/pp.18.00245

Hancock, J. T., and Whiteman, M. (2016). Hydrogen sulfide signaling: interactions with nitric oxide and reactive oxygen species. Ann. N. Y. Acad. Sci. 1365, 5-14.

Hu, H., Liu, D., Li, P., and Shen, W. (2015). Hydrogen sulfide delays leaf yellowing of stored water spinach (Ipomoea aquatica) during dark-induced senescence by delaying chlorophyll breakdown, maintaining energy status and increasing antioxidative capacity. Postharvest Biol. Technol. 108, 8-20.

Hu, K. D., Zhang, X. Y., Wang, S. S., Tang, J., Yang, F., Huang, Z. Q., et al. (2019). Hydrogen sulfide inhibits fruit softening by regulating ethylene synthesis and signaling pathway in tomato (Solanum lycopersicum). HortScience 54, 18241830.

Hu, L. Y., Hu, S. L., Wu, J., Li, Y. H., Zheng, J. L., Wei, Z. J., et al. (2012). Hydrogen sulfide prolongs postharvest shelf life of strawberry and plays an antioxidative role in fruits. J. Agric. Food Chem. 60, 8684-8693. doi: 10.1021/jf300728h

Karlova, R., Chapman, N., David, K., Angenent, G. C., Seymour, G. B., and de Maagd, R. A. (2014). Transcriptional control of fleshy fruit development and ripening. J. Exp. Bot. 65, 4527-4541. doi: 10.1093/jxb/eru316

Kaur, C., and Kapoor, H. C. (2001). Antioxidants in fruits and vegetables: the millennium's health. Int. J. Food Sci. Technol. 36, 703-725.

Klee, H. J., and Giovannoni, J. J. (2011). Genetics and control of tomato fruit ripening and quality attributes. Annu. Rev. Genet. 45, 41-59. doi: 10.1146/ annurev-genet-110410-132507

Lee, H. S., and Wicker, L. (1991). Anthocyanin pigments in the skin of lychee fruit. J. Food Sci. 56, 466-468.

Lee, L., Arul, J., Lencki, R., and Castaigne, F. (2010). A review on modified atmosphere packaging and preservation of fresh fruits and vegetables: physiological basis and practical aspects-part I. Packag. Technol. Sci. 2010, 315-331.

Li, S. P., Hu, K. D., Hu, L. Y., Li, Y. H., Jiang, A. M., Xiao, F., et al. (2014). Hydrogen sulfide alleviates postharvest senescence of broccoli by modulating antioxidant defense and senescence-related gene expression. J. Agric. Food Chem. 62, 1119-1129. doi: 10.1021/jf4047122

Lin, X., Yang, R., Dou, Y., Zhang, W., Du, H., Zhu, L., et al. (2020). Transcriptome analysis reveals delaying of the ripening and cell-wall degradation of kiwifruit by hydrogen sulfide. J. Sci. Food Agric. 100, 2280-2287. doi: 10.1002/jsfa.10260

Liu, M., Pirrello, J., Chervin, C., Roustan, J. P., and Bouzayen, M. (2015). Ethylene control of fruit ripening: revisiting the complex network of transcriptional regulation. Plant Physiol. 169, 2380-2390.

Macoris, M. S., Marchi, D. R., Janzantti, N. S., and Monteiro, M. (2012). The influence of ripening stage and cultivation system on the total antioxidant activity and total phenolic compounds of yellow passion fruit pulp. J. Sci. Food Agric. 92, 1886-1891. doi: 10.1002/jsfa.5556

Miller, G. L. (1959). Use of dinitrosalicylic acid reagent for determination of reducing sugar. Anal. Chem. 31, 426-428.

Nath, A., Bagchi, B., Misra, L. K., and Deka, B. C. (2011). Changes in postharvest phytochemical qualities of broccoli florets during ambient and refrigerated storage. Food Chem. 127, 1510-1514.

Pirie, A., and Mullins, M. G. (1976). Changes in anthocyanin and phenolics content of grapevine leaf and fruit tissues treated with sucrose, nitrate and abscisic acid. Plant Physiol. 58, 468-472. doi: 10.1104/pp.58.4.468

Reimerdes, E. H., and Klostermeyer, H. (1976). Determination of proteolytic activities on casein substrates. Methods Enzymol. 45, 26-28.

Rochette, L., and Vergely, C. (2008). Hydrogen sulfide (H2S), an endogenous gas with odor of rotten eggs might be a cardiovascular function regulator. Ann. Cardiol. Angeiolo. 57, 136-138. doi: 10.1016/j.ancard.2008.02.014
Schelbert, S., Aubry, S., Burla, B., Agne, B., Kessler, F., Krupinska, K., et al. (2009). Pheophytin pheophorbide hydrolase (pheophytinase) is involved in chlorophyll breakdown during leaf senescence in Arabidopsis. Plant Cell 21, 767-785. doi: 10.1105/tpc.108.064089

Staden, J. F. V., and Mulaudzi, L. V. (2000). Flow injection spectrophotometric assay of $\alpha$-amylase activity. Anal. Chim. Acta. 421, 19-25.

Su, L., Diretto, G., Purgatto, E., Danoun, S., Zouine, M., Li, Z., et al. (2015). Carotenoid accumulation during tomato fruit ripening is modulated by the auxin-ethylene balance. BMC Plant Biol. 15:114. doi: 10.1186/s12870-0150495-4

Ubeed, H. M. S. A., Wills, R. B. H., Bowyer, M. C., Vuong, Q. V., and Golding, J. B. (2017). Interaction of exogenous hydrogen sulphide and ethylene on senescence of green leafy vegetables. Postharvest Biol. Technol. 133, 81-87.

Vinha, A. F., Barreira, S. V., Costa, A. S., Alves, R. C., and Oliveira, M. B. (2014). Organic versus conventional tomatoes: influence on physicochemical parameters, bioactive compounds and sensorial attributes. Food Chem. Toxicol. 67, 139-144. doi: 10.1016/j.fct.2014.02.018

Wellburn, A. R. (1994). The spectral determination of chlorophylls a, and b, as well as total carotenoids, using various solvents with spectrophotometers of different resolution. J. Plant Physiol. 144, 307-313.

Yao, G. F., Wei, Z. Z., Li, T. T., Tang, J., Huang, Z. Q., Yang, F., et al. (2018). Modulation of enhanced antioxidant activity by hydrogen sulfide antagonizing ethylene in tomato fruit ripening. J. Agri. Food Chem. 66, 10380-10387. doi: 10.1021/acs.jafc.8b03951

Zhang, A. D., Wang, W. Q., Tong, Y., Li, M. J., Grierson, D., Ferguson, I., et al. (2018). Transcriptome analysis identifies a zinc finger protein regulating starch degradation in kiwifruit. Plant Physiol. 178, 850-863. doi: 10.1104/pp.18. 00427

Zhang, H., Dou, W., Jiang, C. X., Wei, Z. J., Liu, J., and Jones, R. L. (2010). Hydrogen sulfide stimulates $\beta$-amylase activity during early stages of wheat grain germination. Plant Signal Behav. 5, 1031-1033.

Zhang, H., Hu, L. Y., Hu, K. D., He, Y. D., Wang, S. H., and Luo, J. P. (2008) Hydrogen sulfide promotes wheat seed germination and alleviates oxidative damage against copper stress. J. Integr. Plant Biol. 50, 1518-1529. doi: 10.1111/ j.1744-7909.2008.00769.x

Zhang, H., Hu, S. L., Zhang, Z. J., Hu, L. Y., Jiang, C. X., Wei, Z. J., et al. (2011). Hydrogen sulfide acts as a regulator of flower senescence in plants. Postharvest Biol. Technol. 60, 251-257.

Zhang, H., Tang, J., Liu, X. P., Wang, Y., Yu, W., Peng, W. Y., et al. (2009). Hydrogen sulfide promotes root organogenesis in Ipomoea batatas. Salix matsudana and Glycine max. J. Integr. Plant Biol. 51, 1086-1094. doi: 10.1111/ j.1744-7909.2009.00885.x

Zhang, L., Li, S., Liu, X., Song, C., and Liu, X. (2012). Effects of ethephon on physicochemical and quality properties of kiwifruit during ripening. Postharvest Biol. Technol. 65, 69-75.

Zhao, Z. C., Hu, G. B., Hu, F. C., Wang, H. C., Yang, Z. Y., and Lai, B. (2012). The UDP glucose: flavonoid-3-glucosyltransferase, gene regulates anthocyanin biosynthesis in litchi (Litchi chinesis Sonn.) during fruit coloration. Mol. Biol. Rep. 39, 6409-6415. doi: 10.1007/s11033-0111303-3

Zheng, J. L., Hu, L. Y., Hu, K. D., Wu, J., Yang, F., and Zhang, H. (2016). Hydrogen sulfide alleviates senescence of fresh-cut apple by regulating antioxidant defense system and senescence-related gene expression. HortScience 51, $152-158$.

Zhu, L. Q., Wang, W., Shi, J. Y., Zhang, W., Shen, Y., Du, H., et al. (2014). Hydrogen sulfide extends the postharvest life and enhances antioxidant activity of kiwifruit during storage. J. Sci. Food Agric. 94, 2699-2704. doi: 10.1002/jsfa. 6613

Conflict of Interest: The authors declare that the research was conducted in the absence of any commercial or financial relationships that could be construed as a potential conflict of interest.

Copyright (C) 2020 Yao, Li, Sun, Tang, Huang, Yang, Huang, Hu, Jin, Hu and Zhang. This is an open-access article distributed under the terms of the Creative Commons Attribution License (CC BY). The use, distribution or reproduction in other forums is permitted, provided the original author(s) and the copyright owner(s) are credited and that the original publication in this journal is cited, in accordance with accepted academic practice. No use, distribution or reproduction is permitted which does not comply with these terms. 